\title{
Aktivitas Pengungkapan Diri Remaja Putri Melalui Sosial Media Twitter
}

\author{
Ria Yunita
}

Universitas Bina Sarana Informatika

e-mail: ria.rta@bsi.ac.id

Cara Sitasi: Yunita, R. (2019). Aktivitas Pengungkapan Diri Remaja Putri Melalui Sosial Media Twitter. Jurnal Komunikasi, 10(1), 26-32.

\begin{abstract}
The phenomenon of self-disclosure, which is carried out by young women through Twitter is something interesting to study. Twitter becomes an online diary for most users, the term used in microblogs "what are you doing" where twitter users can write their activities, free twitter users reveal anything either just tell what is being done, the purpose of the study to find out self-disclosure young women through twitter social media in Jakarta through the role of Twitter, both in the form of reasons, traits, topics, and values in doing so. The theory used is Adolescent Development Psychology, Self Disclousure theory, and CMC (Computer Mediated Communication). This study uses qualitative methods that are descriptive and with a discourse analysis approach, namely data collected in the form of words and images. The technique of collecting data was in-depth interviews with 3 selected informants. The results of the study are Twitter as a channel for the activities of young women who do self disclosure on Twitter to meet the needs of establishing friendships, especially old friendships and self-actualization. Conclusion, young women (research informants) feel comfortable doing self-disclosure on Twitter, self-disclosure such as status updates in the form of tweets for teenagers are considered more effective to express themselves than tell directly to certain people
\end{abstract}

Keywords: Activity ,Selfdisclosure Girl ,Twitter

\section{PENDAHULUAN}

Manusia berinteraksi dengan manusia lain telah menjadi bagian inti dari kehidupan. Interaksi antar manusia merupakan rutinitas alamiah dalam fenomena hidup. Proses interaksi turut melibatkan proses komunikasi. Terdapat dua tahapan proses komunikasi, yakni proses komunikasi primer dan sekunder. Proses komunikasi primer ialah proses penyampaian pikiran dan atau perasaan seseorang kepada orang lain dengan menggunakan lambang (symbol) sebagai media. Proses komunikasi sekunder yaitu proses penyampaian pesan oleh seseorang kepada orang lain dengan menggunakan alat atau sarana sebagai media kedua setelah memakai lambang sebagai media pertama. (Effendy, 2008)

Alternatif komunikasi masyarakat modern saat ini menyebabkan tuntutan manusia terhadap kebutuhan informasi semakin tinggi. Hal itu turut melahirkan kemajuan yang cukup signifikan dalam bidang teknologi. Peningkatan di bidang teknologi, informasi, serta komunikasi mengakibatkan dunia tidak lagi mengenal batas, jarak, ruang, dan waktu. Seseorang dapat dengan mudah mengakses informasi penting tentang fenomena kejadian di belahan dunia lain, tanpa harus berada di tempat tersebut. Padahal untuk mencapai tempat itu memakan waktu berjam-jam, namun hanya dengan seperangkat komputer yang memiliki

konektivitas internet, informasi dapat diperoleh dalam hitungan detik (Holmes, 2012)

Di era internet ini, jenis media sosial online sangat beragam. Salah satunya yang paling populer adalah Twitter. Twitter telah menjadi online diary bagi sebagian besar penggunannya, istilah yang digunakan dalam mikroblog popular tersebut adalah "what are you doing” yang berarti “apa yang sedang anda lakukan” dimana pengguna twitter dapat menuliskan aktivitasnya, pengguna twitter bebas mengungkapkan apa saja baik itu sekedar memberitahu apa yang sedang dilakukan, dimana posisi penguna saat itu, maupun berbincang dengan pengguna twitter lainnya.

Komunikasi antarpribadi tersebut berupa sebuah self disclosure atau proses mengungkapakan informasi pribadi kita kepada orang lain atau sebaliknya. Membuka diri berarti membagikan kepada orang lain mengenai perasaan kita terhadap sesuatu yang dikatakannya atau dilakukannya, serta perasaanperasaan kita atas suatu kejadian. Self disclosure juga memiliki arti pemberian informasi tentang diri sendiri kepada orang lain dan orang lain tersebut 
tidak akan tahu apabila tidak mendapat informasi tersebut.

Pengungkapan diri dapat berupa berbagai topik seperti informasi perilaku, sikap, perasaan, keinginan, motivasi, ide yang sesuai dan terdapat di dalam diri orang yang bersangkutan.

Pada dasarnya Twitter dibuat dengan niat baik dan benar-benar mengusung nilai-nilai pertemanan yang "kental". Hal itu dapat dilihat pada fitur dan kemampuan seperti membuat pertemanan dan terus dapat berhubungan dengan teman-teman atau relasi, melalui Mention ataupun DM (direct Message), mengirimkan pesan personal layaknya e-mail, saling meng-upload dan sharing image, hastags (\#) dan Trending topic yaiu topik yang sedang ramai di bicarakan oleh tweeps Trending topic bisa bermanfaat bagi corporate branding dalam target pemasaran mereka, bisa pula bermanfaat bagi politikus untuk melihat isu-isu.

Masa remaja merupakan suatu periode dari perkembangan manusia. Masa ini merupakan masa perubahan atau peralihan dari masa kanak-kanak ke masa dewasa yang meliputi perubahan biologik, perubahan psikologik, dan perubahan sosial. Di sebagian besar masyarakat dan budaya masa remaja pada umumnya dimulai pada usia 10-13 tahun dan berakhir pada usia 18-22 tahun (Notoatmojo, 2005)

informan yang diteliti sebanyak 3 orang yang berprofesi sebagai pelajar di salah satu Sekolah Menengah Atas di Jakarta yaitu yang bernama Yeni, Ira, Nina Pendekatan yang akan digunakan peneliti dalam penelitian ini adalah pendekatan kualitatif, dan akhirnya peneliti menggunakan judul “Aktivitas Pengungkapan Diri Remaja Putri Melalui Media Sosial Twitter

\section{Fokus Penelitian}

Bentuk mengekpresikan penmgungkapan diri remaja putri.

2. Pengungkapan diri (self disclosure) remaja putri melalui media sosial twitter.

3. Gaya interaksi remaja putri dengan pengguna twitter lainnya.

4. Keterlibatan remaja putri dalam penggunaan media sosial twitter.

5. Fungsi penggunaan media sosial twitter pada remaja putri. Dengan demikian fokus penelitian ini bagaimana Aktivitas Pengungkapan Diri Remaja Putri Melalui Media Sosial Twitter?

\section{METODOLOGI PENELITIAN}

Little John mengatakan bahwa teori-teori aliran konstruktivis ini berlandaskan pada ide bahwa realitas bukanlah bentukan yang objektif, tetapi dikonstruksi melalui proses interaksi dalam kelompok, masyarakat, dan budaya (John, 2002)

Metode Penelitian dalam penelitian ini adalah dengan menggunakan metode kualitatif yang bersifat deskriptif dan dengan pendekatan analisis wacana (Effendy, 2008)

Penelitian deskriptif digunakan untuk menggambarkan, meringkaskan berbagai kondisi, berbagai situasi atau berbagai fenomena realitas sosial yang ada di masyarakat yang menjadi obyek penelitian, dan berupaya menarik realitas itu kepermukaan sebagai ciri, karakter, sifat, model, tanda, atau gambaran tentang kondisi, situasi ataupun fenomena tertentu (Bungin, 2006)

Situasi atau fenomena tertentu.dengan menggunakan metode kuaitatif, menggunakan analisis wacana dengan mengandalkan penafsiran dari peneiti terhadap objek yang di teliti.analisis wacana merupakan bentuk liguistik formal (Eriyanto, 2001)

Dalam penelitian ini data primer diperoleh dari hasil wawancara mendalam peneliti kepada ketiga informan (subyek penelitian). Wawancara adalah pertemuan tatap muka yang melibatkan interaksi verbal antara dua atau lebih tetapi biasanya diprakarsai untuk suatu maksud khusus dan biasanya difokuskan pada masalah khusus (Ishwara, Catatan Jurnalisme Dasar, 2005)

\section{Sejarah Tweeter}

Twitter adalah salah satu situs social networking dan micro-blogging yang saat ini sangat populer di internet, mungkin kepopuleranya hampir menyamai kepopuleran Facebook. Twitter ini adalah sebagai media bagi kita untuk men-share sesuatu apapun itu melalui sebuah pesan yang biasa disebut dengan tweet. menulis tweet ini dengan cara login ke account Twitter kita, menggunakan softwaresoftware yang dibuat khusus untuk keperluan mengupdate Twitter seperti TwitterDeck, atau bisa juga melalui aplikasi Gadget.

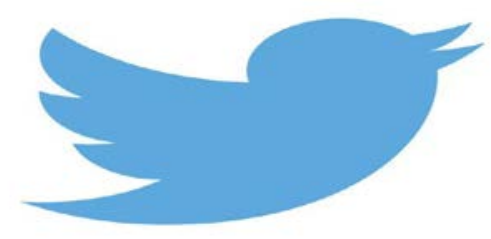

\section{Pertumbuhan Twitter}

Salah bentuk media sosial yang paling cepat pertumbuhanya Twitter pada awalnya diciptakan untuk mendukung pekerjaan, sekarang telah didominasi oleh remaja. 
Pada awalnya digunakan oleh publik figur sebagai basis fans mereka, sekarang Twitter sudah menjadi media komunikasi dikalangan remaja. Mempunyai Twitter dan nge-tweet adalah hal yang lumrah dimanapun dan kapanpun. Kemudahan teknologi

dan dorongan sosial ditingkat pergaulan remaja membuat Twitter menjadi satu icon budaya yang sudah terserap. Twitter sudah menjadi wadah mengungkapkan diri (self disclosure) remaja seharihari. Informasi baru yang realtime membuat remaja merasa selalu terdepan diantara teman-temanya.

\section{Konten Dalam Twitter}

Berikut konten yang terdapat dalam Twitter:

a. Laman Utama (Home)

b. Profil

c. Tweet

d. Mention

e. Timeline

f. Reply

g. Retweet

h. Follow

i. Pengikut (Follower)

j. Ikutan (Following)

k.Favorite

1. Pesan Langsung (Direct Message)

m. Tagar (Hashtag) dengan tanda (\#)

n. Senarai (List)

o. Topik Hangat (Trending Topic)

\section{Gambaran Umum Subyek Penelitian \\ Yeni}

Informan Yeni ini adalah pelajar berusia 18 tahun, anak ke 2 dari 3 bersaudari. Yeni memiliki prestasi akademis yang selalu diatas rata-rata. Begitu pula dengan Yeni, dalam keseharianya Yeni lebih sering mendapatkan dan mencari informasi-informasi yang dibutuhkan melalui akun twitternya Yeni menggunakan twitter sejak tahun 2014.

Dalam kesehariannya sekarang Yeni memilih menggunakan akses internet yang dimilikinya melalui Gadget untuk mencari dan mendapatkan informasi yang dibutuhkan. Hampir di setiap kesempatan, Yeni menggunakan Gadget. nya untuk mencari informasi melalui akun twitter miliknya.

\section{B. Ira}

Remaja yang akrab disapa Ira Dilahirkan tanggal 1 Oktober 1997 di kota Jakarta. Anak bungsu dari 3 bersaudari ini memiliki cita-cita sederhana, cuman hanya ingin membanggakan kedua orang tua. Dan mempunyai hobi bermacammacam, mulai dari membaca, browsing, olahraga, traveling dan menulis. Remaja ini menyebutkan salah satu moto kehidupannya "tulislah apa yang engkau baca dan bacalah apa yang engkau tulis". Sudah sejak tahun 2014 Ira memiliki akun twitter.
Ira memiliki karakter yang tidak malu-malu untuk menujukan ekspresi terhadap pasanganya di akun twittter miliknya. Dalam kesehariannya Ira mendapatkan dan mencari informasi-informasi yang dia butuhkan melalui internet.

\section{Nina}

Pelajar kelahiran Jakarta 18 tahun silam ini merupakan orang yang supel, serta apa adanya sehingga ia ridak sulit untuk mendapatkan teman melalui media sosial khusunya twitter. Nina menggunakan twitter sejak tahun 2015. Hampir setiap memiliki waktu senggang Nina menggunakan handp honenya sebagai media komunikasi yang ia gunakan antara lain Gadget., Browsing, dan Twitter.

\section{HASIL DAN PEMBAHASAN}

\section{Bentuk ekpresi self disclosure remaja putri}

Dalam kehidupan ini kadang-kadang manusia mengalami suatu kekecewaan atau kekesalan, baik itu yang menyangkut pekerjaan, pertemanan, lingkungan ataupun yang lainnya. yang dikatakan oleh saudari Yeni dan Ira pada saat diwawancarai pada hari Minggu, 26 Januari 2019 sekitar pukul $13.00 \mathrm{WIB}$,

menurtu Yeni salah satu alasan memiliki akun twitter, selain untuk mendapatkan teman baru juga sebagai tempat curhat layaknya buku diary untuk melepas unek-uneknya. Misalkan curhat ketika mengenai suatu hal ketika sedang marah dengan teman atau pacarnya.

Bagi Ira twitter adalah media sosial yang dapat memberikan informasi terkini, misalnya dengan memfollow akun @TMCPoldaMetro. Selain berkicau tentang kondisi lalu lintas dan kecelakaan yang terjadi, akun@TMCPoldaMetro juga kerap membagikan tips-tips penting seputar berkendara yang aman. Sedangkan bagi

Bagi Nina twitter adalah media untuk selfie, dengan selfie Nina merasa dapat mengekplorasikan diri, lebih-lebih apabila ada yang berkomentar bagus tentang foto tersebut.

Yeni memiliki suatu cara pengelolaan tersendiri dalam dirinya ketika berusaha untuk mencapai keputusan final ketika akan mengungkapkan suatu ke dalam bentuk tweets. Tapi harus diawali dengan munculnya mood yang tepat terlebih dahulu, dan biasa sering dilakukan dimalam hari pada saat belum bisatidur atau pada saat sudah tidak ada lagi acara yang menarik di televisi. "tergantung mood kali

yah..aku lagi gimana, lagi keinget mantan yang ngeselin, atau lagi pengen curhat tentang sesuatu, biasanya malam hari..apalagi kalo udah ga ada film bagus di TV, terus gak bisa tidur" 
Saudari Ira menggunakan mood sebagai patokan dalam mengungkapkan informasi diri tetapi desakan untuk melakukan pengungkapan biasanya dating secara spontanitas dan dengan sedikit pertimbangan, apa yang sedang terlintas di kepalanya bisa saja langsung dijadikan tweet. Ira juga selalu memnafaatkan waktu libur sekolah untuk mengecek akun twitternya.

\begin{abstract}
“spontanitas ajah mba, pokonya sih apa yang ada dikepala, pikir sebentar itu sesuai apa engga, trus ketik trus update tweet..hahahahah, dirumah sehabis pulang sekolah, waktunya bisa kapan ajah, yang penting tidak mengganggu belajar..kan ini lagi libur mba, jadi sering banget aku maen twitter, posting-posting dan liat-liat tweets teman-teman. Ini saya anggap sebagai hiburan kalau lagi senggang dan libur sekolah"
\end{abstract}

Sedangkan bagi Yeni ketika akan mengungkap suatu dalam bentuk tweet, ia akan harus menunggu waktu luang, namun ketika waktu luang itu datang, ia bisa langusng ngetweet banyak. Seperti yang dikatakan pada saat wawancara berikut:

\section{"biasanya kalo waktu luang, di sekolah atau pas nunggu guru dan teman, aku selalu lari ke twitter, kalo gak update tweets ya liat-liat timeline temen- temen atau melihat informasi terbaru melalui beberapa akun yang aku follow, sekali nya update bisa langsung 5 kali ngetweet."}

\section{Jenis Gadget yang Digunakan}

Media sosial Twitter yang menawarkan kemudahan berbagai informasi dimana dan kapan saja membuat media sosial ini menjadi hal yang diadopsi menjadi bagian dalam kehidupan sehari-hari remaja, seperti pada saudari Yeni. Yeni ingin memaksimalkan gadget nya. Saudari Yeni menganggap Twitter adalah bagian tak terpisahkan dalam kehidupan sehari-harinya. Interaksi Yeni dengan lingkungan lebih banyak terjadi dalam Twitter. Tanpa harus ikut berpartisipasi dalam Twitter Yeni merasa juga mendapatkan berbagai informasi.

Bagi saudari Ira pun media sosial Twitter merupakan media komunikasi utama dalam lingkunganya. Dalam lingkungannya saudari Ira komunikasi melalui media sosial Twitter lebih cepat mendapat respon dibandingkan media lainnya. Media sosial Twitter tidak dapat dipisahkan dari dari hidup Ira. Bagi saudari Ira, Twitter adalah media komunikasi utama sehari-hari. Twitter adalah salah satu media yang diusahakan Ira untuk dijaga aksesnya. Kehilangan akses ke Twitter kurang bias ditolerir oleh Ira. Ketika berkomunikasi menggunakan Twitter respon yang didapat Ira jauh lebih cepat dibandingkan media lainnya.

"yah gelisah, penasaran. Hhhm kaya kemaren mba, pas pulsa abis mau gak mau bela-belain panas-panasan jalan ke depan, buat beli pulsa deh. Terus daftar lagi deh, trus bisa online twitteran lagi deh..hehehehe...susahkalo Gadget mati, bisa mati gaya mba.."

Sedangkan bagi saudari Nina media sosial Twitter adalah sebuah media komunikasi yang awalnya harus dipaksakan oleh lingkungan sekitarnya namun sekarang Nadya dapat mempergunakan Twitter dengan sebaik-baiknya.

“yaaap...awalnya aku males, karena gak ngerti sih sebenernya..tapi setelah didesak-desak kanan-kiri atas-bawah yah aku galah, akhirnya aku bikin twitter deh, lama kelamaan setelah kebiasaan baru deh pandangan aku berubah, twitter itu gampang, mobile dan fast respon”

Nina merasa Twitter penting dalam keseharianya karena informasinformasi yang dibutuhkan dirinya tersedia lengkap. Bagi Nina sekarang ini, informasiinformasi yang terdapat pada media sosial Twitter memegang peranan tersendiri dalam menunjang aktifitas kesehariannya. Nina termasuk individu yang tidak begitu suka untuk mengikuti trend seperti remaja lain pada umumnya.

\section{Media yang Digunakan}

Dalam mendapatkan dan mencari informasiinformasi yang dibutuhkan saudari Yeni menggunakan Facebook, Twitter, Foursquare, Google melalui Gadgetnya. Penggunaan gadget oleh saudari Yeni sangat tinggi, karena hampir disetiap kesempatan.

Ketika online saudari Yeni lebih sering menggunakan waktunya itu untuk mengakses beberapa media sosial. Dari bebarapa media sosial yang digunakan oleh saudari Yeni, Twitter merupakan media sosial yang paling sering diakses saudari Yeni. Gadget digunakan karena praktis dan efisien bagi Yeni . dalam dan kesehariannya sms adalah fitur layanan yang jarang lagi digunakan karena sekarang sekitarnyasudah menggunakan Gadget.

Ira menggunakan waktu online untuk bermedia sosial dan berbincang.Facebook bagi Ira telah kurang intensitas penggunaanya. Saudari Icha lebih sering menggunakan Twitter bila dibandingkan Facebook dalam kesehariannya.

Saudari Ira menggunakan gadget untuk mengakses internet dan memaksimalkan fungsi gadget tersebut. Dari sekian banyak media sosial Icha lebih memilih menggunakan Twitter dalam berinteraksi dibandingkan dengan Facebook. Sama seperti Yeni dan Icha, saudari Nin pun menggunakan gadgetya dalam mengakses internet dalam kesehariannya. 
Nina menggunakan waktu onlinenya untuk berbincang dan mencari informasi didunia maya.

Dan Nina juga mengakses beberapa media sosial seperti Facebook, Twitter, dan detik. Twitter adalah media sosial yang lebih sering digunakan dalam keseharian Nadya dibandingkan dengan Facebook atau media sosial lainnya. Lingkungan Nina rata-rata memiliki gadget ,sehingga membuat Nina merasa akses ke lingkungan sekitarnya lebih mudah menggunakan Facebook. Tetapi Nina akan menggunakan kembali akun Facebooknya bila ada keperluan tertentu. Saudari Nina awalnya mengakses internet dari laptop pribadinya tetapi setelah memiliki gadget, Nina lebih memilih Gadget sebagai media utama untuk mengakses internet.

Selain Twitter, saudari Ira mengaku juga memiliki Facebook namun tidak aktif menggunakannya. Ira lebih merasa nyaman untuk menggunakan media sosial Twitter dibandingkan Facebook. Dalam hal penggunaan media sosial seperti Twitter dan Facebook, saudari Nina lebih sering menggunakan Twitter seperti kutipan wawancara berikut:

“Twitter sih, Facebook biasanya buat upload foto doank anggep ajah kaya album poto pribadi. Hahaha..." $\square$ Frekuensi Penggunaan Twitter

Jumlah tertentu bisa dilihat berdasarkan frekuensi informan penyampaian pesan-pesan dalam ukuran waktu yakni berapa lama informan menyampaikan pesan-pesan yang mengandung self disclosure pada keseluruhan kegiatan komunikasi informan dengan lawan komunikasinya. Saudari Yeni dapat menghabiskan waktu nya dengan mengetweet sesuatu hingga lebih dari 10 kali.

\author{
“waduh berapa yah? soalnya aku sering banget \\ mba, setiap hari banyak, \\ lebih dari 10 pasti”
}

Bagi saudari Ira tweet yang ia tilis tergantung dengan kondisi saat itu, Ira merasa jika ada sesuatu yang menarik ia bisa tulis dalam bentuk tweet.

\footnotetext{
“perkiraan lebih dari 10 kali, kadang kalo misalkan ada topik yang menarik bisa lebih lagi lah, lebih dari 20"

Sedangkan bagi saudari Nina, untuk menulis sesuatu di twitternya, dia bisa sampai 15 tweet per harinya, semua apa yang ia rasakan dan alami atau sedang dimana dirinya akan tulis dalam bentuk tweet.

"rata-rata sehari bisa sampai 15 tweet palingan pokonya setiap menit yang saya rasakan atau alami saya tweet di akun twitter saya Pengungkapan Diri (self disclosure) Remaja Putri melalui Media Sosial Twitters
}

Saudari Yeni mengatakan sindir-sindiran di media sosial seperti Twitter saat ini sudah menjadi hal yang biasa, berawal dari rasa kecewa, sakit hati, bahkan hanya sekedar iseng kurang kerjaan. Yeni pun pernah melakukan hal tersebut. Yeni pernah dikecewai oleh temannya dan dia pernah menulis tweet di akun twitter nya pada 20 Januari 2019, 11:35

\section{“ ternyataaaa oh ternyataaaa... ku dipermainkan oleh diaaaa... dia yg kuanggap teman !!!!"”}

Semangat dalam menjalani hari-hari pun kurang bersemangat dan cenderung akan melamun memikirkan hal tersebut yang selalu membayangi perasaan. Perasaan seperti itu lah yang sering Ira ungkap dalam akun twitternya. Berikut contoh kalimat galau yang pernah Ira tulis di akun twitter nya pada 16 Januari 2019 06:18 pm

\section{"berusaha ikhlas untuk kehilangan mencoba tersenyum dari sebuah ujian pesakitan”.}

namun disisi lain Ira juga update tweets menulis kalimat motivasi untukt eman atau untuk followernya, misalnya “ Saudari Yeni merasa dengan mengungkap diri nya ke dalam tweet maka Yeni akan mendapat apa yang diharapkan, Perasaan lega adalah yang didapat dari setiap ungkapan Yeni. Hal yang sama juga dirasa oleh saudari Ira.

Saudari Nina mempunyai batasan-batasan tersendiri dalam mengungkap informasi privat dalam tweet. Dan Nina berpandangan terkadang ada saat dimana batasan-batasan mengenai informasi privat tersebut bisa dan perlu untuk diterobos dan juga dipinggirkan. Senada dengan saudari Yeni, Nina mengatakan batasan dirinya dalam mengungkapkan informasi dalam bentuk tweet adalah norma-norma dan hukum yang berlaku.

\section{Keterlibatan Remaja Putri dalam Penggunaan Media Sosial Twitter}

Media sosial Twitter yang menawarkan kemudahan berbagi informasi dimana dan kapan saja membuat media sosial ini menjadi hal yang diadopsi menjadi bagian dalam kehidupan sehari-hari remaja, seperti pada saudari Yeni. Saudari Icha merasa Twitter penting dalam kesehariannya karenai nformasiinformasi yang dibutuhkan dirinya tersedia lengkap.

Bagi Ira sekarang ini, informasi-informasi yang terdapat pada situs media sosial Twitter memegang peranan tersendiri dalam menunjang aktifitas keseharianya. Bagi saudari Nina Twitter tersebut menyediakan informasi-informasi yang dibutuhkan Nina sehari-hari dan juga merupakan salah satu bentuk ungkapan diri dan perasaanya. Beberapa akun yang di follow oleh saudari Yeni sejak awal 
bermain Twitter sampai saat ini, akun-akun yang di follow ini merupakan sumber informasi bagi Yuyun. Seperti akun,@SoalAsmara, detikcom,@metroTV, bagi Yeni akun-akun Twitter tersebut menyediakan informasiinformasi yang dibutuhkan Yeni seharihari dan juga merupakan salah satu bentuk ungkapan diri dan perasaanya.

Sedangkan bagi saudari Ira, akun-akun yang pertama di follow oleh Icha dalam Twitter adalah temanteman personalnya, lalu Icha mencari akun-akun yang dapat menjadi sumber informasibagi dirinya sehari-hari. Seperti akun @detikcom, @SoalAsmara akun artis-artis. Pertimbangan saudari Ira dalam memfollolw suatu akun Twitter adalah kebutuhan diri Icha akan informasi yang dapat disediakan akunakun tersebut dalam setiap tweetnya.

Saudari Ira menyukai akun @SoalAsmara karena tweet-tweetnya menggambarkan dirinya dan mengekspresikan pikirannya. Tweet-tweet dari akun @SoalAsmara merupakan hal yang sangat menarik bagi saudari Yeni. Akun-akun mendapat prioritas untuk Ira follow adalah teman-teman, lalu akun-akun yang merupakan sumber informasi bagi Ira didalam berTwitter.

Begitu pula dengan saudari Nina, dirinya memfollow akun-akun Twitter yang dapat memberikan informasi yang diinginkan dirinya, seperti akun @SoalAsmara@pepatah, @Zodiacfact. Bagi Nina, dirinya memfollow akun-akun tersebut karena informasi-informasi yang disediakan akunakun tersebut sesuai dengan kebutuhan informasi seharihari Nina dan juga kegiatan utama berTwitter bagi Ninaadalah follow dan memfollow.

Saudari Yeni lebih membatasi dalam mengekpresikan diri melalui tweets. Namun disisi lain, Yeni menjadi lebih sering menggunakan iconicon yang tersedia dalam Twitter untuk mengekspresikan perasaanya. Dalam mengungkap perasaan dengan pacarnya, saudari Icha lebih sering menggunakan simbol-simbol dibandingkan dengan kata-kata yang ditulis panjang.

\section{Penggunaan Media Sosial Twitter oleh Remaja Putri.}

Dalam melakukan self disclosure, salah satu hal yang saudari pertimbangkan adalah maksud dan tujuan. Tidak mungkin orang tiba-tiba menyatakan dirinya apabila dirinya tidak memiliki maksud dan tujuan tertentu.

Saudari Yeni merasa dengan mengungkap diri nya ke dalam tweet maka Yeni akan mendapat keuntungan yang diharapkan, meskipun ada kerugian yang harus ditanggungnya. Perasaan lega adalah keuntungan yang didapat dari setiap ungkapan Yeni.

Berdasarkan hasil penelitian yang peneliti lakukan dengan cara wawancara terhadap ketiga informan langsung sebagai pengguna aktif Twitter di kalangan remaja putri yaitu yang bernama Yeni, Ira dan Nina. Maka, peneliti dapat menjelaskan secara terperinci permasalah yang menjadi objek penelitian dan menerangkan secara keseluruhan tentang aktivitas pengungkapan diri remaja putri melalui media sosial Twitter.

Pada pembahasan ini peneliti menguraikan hasil penelitian mengenai Twitter telah menjadi online diary bagi sebagian besar penggunannya, istilah yang digunakan dalam mikroblog popular tersebut adalah "what are you doing” yang berarti “apa yang sedang anda lakukan” dimana pengguna twitter dapat

Pengungkapan diri pada remaja putri pengguna Twitter, memberikan hasil bahwa ke 3 remaja putri yang menjadi subyek penelitian lebih suka berbagi dengan menggunakan Twitter karena bagi mereka dengan menceritakan diri lewat Twitter, mereka akan lebih banyak memperhatikan dan dukungan dari banyak orang.

Suatu interaksi antara individu dengan orang lain, akan ada yang menerima dan menolak dan bagaimana orang lain Keterbukaan diri ini dapat berupa deskriptif atau evaluatif. ialah individu melukiskan berbagai cerita fakta mengenai pribadi diri yang tidak di ketahui oleh orang lain seperti alamat dan usia.

Sedangkan evaluatif artinya individu mengemukakan pendapat atau perasaan pribadinya seperti tipe orang yang disukai atau dibenci. Self disclosure atau keterbukaan diri remaja di Twitter dapat berpotensi baik ataupun buruk yang ditimbulkan Twitter. Keterbukaan seseorang dapat menentukan hubungan dengan individu lainnya. Hubungan tersebut dapat dilihat dari tingkat keluasan dan kedalaman topik pembicaraan. Keterbukaan diri sangat terkait dengan konsep diri individu.

Apabila konsep diri individu positif, maka keterbukaan diri yang dimunculkan positif pula bagi individu tersebut. Sebaliknya apabila konsep diri individu negatif, maka ada keterbukaan diri dan dampak yang didapat dari individu tersebut cenderung negatif.

\section{KESIMPULAN}

Berdasarkan hasil penelitian dan pembahasan, peneliti sampai pada simpulan sebagai berikut: 
1. Jumlah self disclosure yaitu jumlah pesan yang diungkap, dalam hal ini adalah jumlah tweet yang mengandung pesan mengungkap diri. Informan mengungkap diri mereka rata-rata antara 5-10 tweet setiap hari nya. Semua informan merasa percaya diri ketika mereka memiliki akun Twitter dan aktif dalam penggunaanya. Hal ini terlihat dari frekuensi posting yang mereka lakukan.

2. Valensi self disclosure, terkait dengan positif dan negatif pesan pengungkapan diri yang dilakukan. Self disclosure yang positif berupa motivasi diri dan memotivasi orang lain, pengungkapan kesenangan dan kegembiraan. Self disclosure yang negatif lebih banyak dilakukan dalam bentuk ungkapan marah kepada seseorang atau kelompok tertentu yang dilakukan secara langsung dan tidak langsung, kemudian mengeluh terhadap situasi yang sedang mereka alami.

3. Dalam penelitian ini peneliti menilai bahwa informan telah melakukan self disclosure dengan cermat, mereka memahami dengan baik bagaiman posisi mereka dihadapan follower dan bagaiman pesan yang mereka ungkapkan. Informan lebih jujur dalam mengungkap diri , sikap apa danya bahkan cenderung blak-blakan. Ketika ada ketidakjujuran yang dilakukan itu hanya dilakukan untuk bercanda dengan temannya dan tidak sengaja berbohong untuk mendapatkan simpati dari orang lain.

4. Kedalaman untuk mengenal teman yang dijadikan sebagai tempat untuk mengungkap diri. Dalam penelitian ini peneliti menemukan bahwa informan menjadi mengenal lebih dalam dan lebih akrab dengan teman-temannya yang ada di Twitter. Keluasan bahasan yang mencakup beberapa aspek, dan semua aspek baik itu aspek opini, hobi dan minat, pendidikan, kepribadian, dan aspek fisik yang ada pada informan. Tetapi tidak semua dari mereka mengungkap semua aspek terebut.

\section{REFERENSI}

Bungin, B. (2006). Analisis Data Penelitian Kualitatif. Jakarta: Raja Grafindo Persada.
Desmita. (2013). Psikologi Perkembangan. Bandung: Remaja Rosdakarya.

Effendy, O. U. (2008). Dinamika Komunikasi. Bandung: Remaja Rosdakarya.

Eriyanto. (2001). Analisis Wacana Pengantar Analisis Isi Media. Yogyakarta: LKIS.

Holmes, D. (2012). Teori Komunikasi Massa. Jakarta: Salemba Humanika.

Ichsan. (2013, November). Sistem Pendukung Keputusan Pemilihan Penerima Beasiswa Mahasiswa Kurang Mampu Pada STMIK BUDIDARMA Medan Menerapkan Metode Profile Matching. Kursor, 5(1), 2.

Ishwara, L. (20025). Catatan Jurnalisme Dasar. Jakarta: Kompas Gramedia.

Ishwara, L. (2005). Catatan Jurnalisme Dasar. Jakarta: Kompas Gramedia.

John, S. W. (2002). Theoris of Human Communication. Wadsworth: Belmont.

Morissan. (2008). Manajemen Media Media PenyiaranStrategi Mengelola Radio dan Televisi. Kencana Jakarta: 210-211.

Mulyana, D. M. ( 2004). Metodologi Penelitian Kualitatif. Bandung: PT Remaja Rosdakarya.

Notoatmojo. (2005). Promosi Kesehatan Teori dan Aplikasi. Jakarta: Rineka Cipta.

\section{PROFIL PENULIS}

\section{Ria Yunita, S. I.Kom, M. I.Kom}

lahir di Jakarta 29 Januari 1987 adalah seorang Dosen Program Studi Penyiaran di Akademi Komunikasi Bina Sarana Informatika. memulai karir sebagai dosen di Bina Sarana Informatika sejak 07 Maret 2015. Menyelesaikan studi S1 ( Sarjana Ilmu Komunikasi) pada tahun 2014 jurusan broadcasting dan S2 ( Magister Ilmu Komunikasi) September 2016 jurusan Media Industri dan Bisnis di Univ Mercubuana Jakarta, Penulis sangat menyukai dunia pendidikan dan berkecimpung sebagai tenaga pengajar. Di sela-sela kesibukanya sebagai dosen Beiau adalah seorang penyiar radio dan pengisi suara infotainment, dokumenter dan iklan tv radio. 